\title{
DNA binding and cleavage activity by a mononuclear iron(II)Schiff base complex: Synthesis and structural characterization
}

\author{
ABHIJIT PAL ${ }^{1}$, BHASKAR BISWAS ${ }^{1, \$}$, MERRY MITRA $^{1}$, \\ SUBRAMANIYAM RAJALAKSHMI ${ }^{2}$, CHANDRA SHEKHAR PUROHIT ${ }^{3}$, \\ SOUMITRA HAZRA ${ }^{4}$, GOPINATHA SURESH KUMAR ${ }^{4}$, \\ BALACHANDRAN UNNI NAIR ${ }^{2, *}$ and RAJARSHI GHOSH ${ }^{1, *}$ \\ ${ }^{1}$ Department of Chemistry, The University of Burdwan, Burdwan 713 104, India \\ \$Present address: Department of Chemistry, Raghunathpur College, Purulia 723 133, India \\ ${ }^{2}$ Chemical Laboratory, CSIR-Central Leather Research Institute, Adayar, Chennai 600 020, India \\ ${ }^{3}$ Department of Chemical Sciences, National Institute of Science Education and Research, \\ Bhubaneswar 751 005, India \\ ${ }^{4}$ Biophysical Chemistry Laboratory, Chemistry Division, CSIR-Indian Institute of Chemical Biology, \\ Kolkata 700 032, India \\ e-mail: rajarshi_chem@yahoo.co.in; bunair@clri.res.in
}

MS received 21 January 2013; revised 9 May 2013; accepted 24 June 2013

\begin{abstract}
Synthesis and characterization of a mononuclear Fe(II) compound $[\mathrm{Fe}(\mathrm{L})]\left(\mathrm{ClO}_{4}\right)_{2}(\mathbf{1})[\mathrm{L}=$ $\mathrm{N}$-(1-pyridin-2-yl-phenylidene)- $\mathrm{N}^{\prime}$-[2-(\{2-[(1-pyridin-2-ylphenylidene)amino]ethyl $\}$ amino)ethyl] ethane-1,2diamine] (1) is reported. 1 crystallizes in P-1 space group with $\mathrm{a}=11.9241(3) \AA, \mathrm{b}=12.1994(3) \AA$ and $\mathrm{c}=$ 13.0622(4) $\AA$. The binding property of the complex with DNA has been investigated using absorption and emission studies, thermal melting, viscosity experiments and circular dichroism studies. The binding constant $\left(K_{\mathrm{b}}\right)$ and the linear Stern-Volmer quenching constant $\left(K_{\mathrm{sv}}\right)$ of the complex have been determined as $3.5 \times 10^{3} \mathrm{M}^{-1}$ and $2.73 \times 10^{4} \mathrm{M}^{-1}$, respectively. Spectroscopic and hydrodynamic investigations revealed intercalative mode of binding of $\mathbf{1}$ with DNA. 1 is also found to induce oxidative cleavage of the supercoiled pUC 18 DNA to its nicked circular form in a concentration dependent manner.
\end{abstract}

Keywords. Iron(II); Schiff base; X-ray structure; DNA binding; DNA cleavage.

\section{Introduction}

Design and synthesis of small synthetic systems that can recognize specific sites of DNA through formation of non-covalently associated complexes is an important area of much current interest. ${ }^{1}$ Such physical complexation, more often, may produce important pharmacological effects by interfering with the biological processes in which DNA/RNA takes part. Such investigations also sometimes provide insights for the mechanism of action for antitumour antibiotics. ${ }^{2}$ The metal complexes can interact through $\pi \ldots \pi$ interaction with the DNA base pairs by intercalation when the ligand contains planar heterocyclic ring systems, groove binding for large molecules through hydrogen bonding and van der Waals interaction, or external electrostatic binding for cationic species. ${ }^{3}$ The binding modes are dependent on the sizes and stereochemical preferences of the metal complexes. It would be

*For correspondence valuable to understand quantitatively the contribution from these different modes to the stabilization of the bound complex at a DNA site. Furthermore, binding may induce cleavage of nucleic acids may be considered as an enzymatic reaction which comprises of various biological processes as well as biotechnological manipulation of genetic material. ${ }^{1-4}$ We have been interested in designing metal complex molecules ${ }^{5}$ which can specifically interact with DNA. In this direction, we have designed and synthesized a new $\mathrm{Fe}(\mathrm{II})$ molecule $[\mathrm{Fe}(\mathrm{L})]\left(\mathrm{ClO}_{4}\right)_{2}(\mathbf{1})[\mathrm{L}=$ $\mathrm{N}$-(1-pyridin-2-yl-phenylidene)-N $\mathrm{N}^{\prime}$-[2-(\{2-[(1-pyridin2-ylphenylidene)amino]ethyl \}amino)ethyl]ethane-1, 2-diamine] whose binding ability with Calf ThymusDNA (CT-DNA) at various concentration is investigated. Effects of such binding on the thermal melting, circular dichroism and viscosity of DNA are also presented in this report. It is also found that $\mathbf{1}$ cleaves supercoiled pUC 18 DNA to its nicked circular form in a concentration dependent manner in the presence of hydrogen peroxide as external additives. 


\section{Experimental}

\subsection{Preparation of the complex}

2.1a Chemicals, solvents and starting materials: High purity 2-benzoylpyridine (Fluka, Germany), iron(III) chloride (E Merck, India), sodium perchlorate (E Merck, India), 2-benzoyl pyridine (Aldrich, UK) and triethylenetetraamine (Aldrich, UK) were purchased from the respective companies and used as received. The CT-DNA, agarose and ethidium bromide (EB) were obtained from Sigma. The pUC 18 was purchased from Bangalore Genei. For viscosity studies, the DNA sample was dissolved in the experimental buffer and sonicated to uniform size of about $280 \pm 50$ base pairs using a Labsonic 2000 sonicator (B Braun, Germany) using a needle probe of $4 \mathrm{~mm}$ diameter. The sonicated DNA sample was dialyzed several times against the experimental buffer under sterile conditions in a cold room and stored at $5^{\circ} \mathrm{C}$ till use.

Caution! Perchlorate salts of metal ions are potentially explosive, especially in the presence of organic ligands. Only a small amount of material should be prepared and it should be handled with care.

2.1b Preparation of $L$ and 1 : The Schiff base $L$ was prepared following a reported method ${ }^{6}$ with a little modification. The details are given below:

2-Benzoylpyridine $(0.366 \mathrm{~g}, 2 \mathrm{mmol})$ was refluxed with triethylenetetramine $(0.146 \mathrm{~g}, 1 \mathrm{mmol})$ in dehydrated alcohol $\left(15 \mathrm{~cm}^{3}\right)$. After $10 \mathrm{~h}$ the reaction solution was evaporated under reduced pressure to yield a gummy mass, which was dried and stored in vacuo over $\mathrm{CaCl}_{2}$ for subsequent use. Yield: $3.820 \mathrm{~g}(80 \%)$. Anal. Calc. for $\mathrm{C}_{30} \mathrm{H}_{32} \mathrm{~N}_{6}$ (L): C, 75.38; H, 6.74; N, 17.58. Found: C, 74.98; H, 6.41; N, $17.20 \%$. IR (KBr, $\left.\mathrm{cm}^{-1}\right): 1590\left(v_{\mathrm{C}=\mathrm{N}}\right)$. UV-Vis $\left[\lambda_{\max }, \mathrm{nm}\left(\right.\right.$ lit $\left.\mathrm{mol}^{-1} \mathrm{~cm}^{-1}\right)$, $\mathrm{MeOH}]: 257\left(2.5 \times 10^{4}\right)$.

A methanolic solution $\left(5 \mathrm{~cm}^{3}\right)$ of $\mathrm{L}(0.476 \mathrm{~g}, 1 \mathrm{mmol})$ was added drop-wise to a solution of $\mathrm{FeCl}_{3}(0.162 \mathrm{~g}$, $1 \mathrm{mmol})$ in the same solvent $\left(10 \mathrm{~cm}^{3}\right) . \mathrm{NaClO}_{4}(0.245 \mathrm{~g}$, $2 \mathrm{mmol}$ ) was mixed finally in the reaction mixture. The deep bluish solution with brown tinge was filtered and the supernatant liquid was kept in air for slow evaporation. After about a week, light yellow coloured crystals appeared.

Yield: $0.474 \mathrm{~g}(65 \%$ based on metal salt). Anal. Calc. for $\mathrm{C}_{30} \mathrm{H}_{30} \mathrm{~N}_{6} \mathrm{Cl}_{2} \mathrm{O}_{8} \mathrm{Fe}$ (1): C, 49.35; H, 4.11; $\mathrm{N}, 11.52$. Found: $\mathrm{C}, 51.30 ; \mathrm{H}, 4.17 ; \mathrm{N}, 12.00 \% . \Lambda_{\mathrm{M}}$ : $232 \Omega^{-1} \mathrm{~cm}^{2} \mathrm{~mol}^{-1}$.IR $\left(\mathrm{KBr}, \mathrm{cm}^{-1}\right): 1618,1592\left(\mathrm{v}_{\mathrm{C}=\mathrm{N}}\right)$, 1084, $625\left(\mathrm{v}_{\mathrm{ClO} 4}\right)$; UV-Vis $\left[\lambda_{\max }, \mathrm{nm}\right.$ (lit $\left.\mathrm{mol}^{-1} \mathrm{~cm}^{-1}\right)$, $\mathrm{MeOH}]: 278\left(2.5 \times 10^{4}\right), 362\left(0.56 \times 10^{4}\right), 507(0.49 \times$ $\left.10^{4}\right), 612\left(1.76 \times 10^{4}\right) \mathrm{nm} . \Lambda=242 \Omega^{-1} \mathrm{~cm}^{2} \mathrm{~mol}^{-1}$; $\mu_{\text {spin only }}=4.10 \mathrm{BM}, \mathrm{m} / \mathrm{z}=631.07$ (molecular ion peak); ${ }^{1} \mathrm{H}$ NMR $\delta(\mathrm{ppm}): 8.8(\mathrm{~d}, \mathrm{~J}=3.5 \mathrm{~Hz}, 2 \mathrm{H}), 7.6(\mathrm{~d}$, $\mathrm{J}=1.5 \mathrm{~Hz}, 12 \mathrm{H}), 7.4(\mathrm{~d}, \mathrm{~J}=2.9 \mathrm{~Hz}, 4 \mathrm{H}), 4.1(\mathrm{~d}, \mathrm{~J}=$ $0.82 \mathrm{~Hz}, 4 \mathrm{H}), 3.7(\mathrm{~s}, \mathrm{~J}=1.4 \mathrm{~Hz}, 4 \mathrm{H}), 3.1(\mathrm{~d}, \mathrm{~J}=0.62$, $4 \mathrm{H})$.

\subsection{Physical measurements}

Elemental analyses (carbon, hydrogen and nitrogen) were performed on a Perkin-Elmer $2400 \mathrm{CHNS} / \mathrm{O}$ elemental analyzer. IR spectra ( $\mathrm{KBr}$ discs, $4000-300 \mathrm{~cm}^{-1}$ ) were recorded using a Perkin-Elmer FT-IR model RX1 spectrometer. Ground-state absorption and steady-state fluorescence measurements were made with a Jasco model V-530 UV-Vis spectrophotometer and Hitachi model F-4010 spectrofluorimeter, respectively.

\section{$2.3 X$-ray diffraction}

Single crystals of $\mathbf{1}$ suitable for X-ray crystallographic analysis were selected following examination under a

Table 1. Crystallographic parameters for $\mathbf{1}$.

\begin{tabular}{llll}
\hline Parameters & \multicolumn{1}{c}{$\mathbf{1}$} & \multicolumn{1}{c}{ Parameters } & \multicolumn{1}{c}{$\mathbf{1}$} \\
\hline Emperical formula & $\mathrm{C}_{30} \mathrm{H}_{30} \mathrm{~N}_{6} \mathrm{Cl}_{2} \mathrm{O}_{8} \mathrm{Fe}$ & $\gamma\left(^{\circ}\right)$ & $73.624(2)$ \\
Formula weight & 729.42 & Volume $\left(\AA^{3}\right)$ & $1629.34(8)$ \\
Temperature $(\mathrm{K})$ & $296(2)$ & $\mathrm{Z}$ & 2 \\
Crystal system & Triclinic & $\rho\left(\mathrm{gcm}^{-3}\right)$ & 1.49 \\
Space group & $\mathrm{P}-1$ & $\mu\left(\mathrm{mm}^{-1}\right)$ & 0.686 \\
$\mathrm{a}(\AA)$ & $11.9241(3)$ & $\mathrm{F}(000)$ & 756 \\
$\mathrm{~b}(\AA)$ & $12.1994(3)$ & Crystal size $(\mathrm{mm})$ & $0.66 \times 0.50 \times 0.46$ \\
$\mathrm{c}(\AA)$ & $13.0622(4)$ & $\mathrm{R}($ reflections $)$ & 0.05 \\
$\alpha\left({ }^{\circ}\right)$ & $73.611(2)$ & wR2 (reflections) & 0.156 \\
$\beta\left({ }^{\circ}\right)$ & $65.5370(10)$ & & \\
\hline
\end{tabular}


microscope. Diffraction data at 296(2) K were collected on a Bruker-Kappa APEX II CCD diffractometer using Mo-K $\alpha$ radiation $(\lambda=0.71073 \AA)$. The crystal data and data collection parameters are listed in table 1 . The compound crystallized in P-1 space group. Of 27671 reflections collected, the 8706 unique reflections with I $>2 \sigma(\mathrm{I})$ were used for structure solution. The structure was solved by direct methods, and the structure solution and refinement were based on $|F|^{2}$. The final differences Fourier map showed the maximum and minimum peak heights at -0.905 and $0.560 \mathrm{e}^{-3}$ for 1 with no chemical significance. All calculations were carried out using SHELXL-97 ${ }^{7}$ and ORTEP-32. ${ }^{8}$

\subsection{Thermal melting}

Absorbance versus temperature profiles (optical melting curves) of DNA and iron(II)Schiff base complexDNA were measured on the Shimadzu Pharmaspec 1700 unit (Shimadzu Corporation, Kyoto, Japan) equipped with the peltier controlled TMSPC- 8 model accessory in eight-chambered quartz cuvette of $1 \mathrm{~cm}$ path length. The temperature was ramped from 40 $100^{\circ} \mathrm{C}$ at a scan rate of $0.5^{\circ} \mathrm{C} / \mathrm{min}$ monitoring the absorbance changes at $260 \mathrm{~nm}$. $T_{\mathrm{m}}$ is taken as the midpoint of the melting transition as determined by the maxima of the first derivative plots.

\subsection{Viscosity measurements}

For viscosity studies sonicated DNA of (280 \pm 40 base pairs) was used. The viscosity of the DNA-metal complex was determined by measuring the time needed to flow through a Cannon-Manning semi micro size 75 capillary viscometer (Cannon Instruments Company, State College, PA, USA) that was submerged in a thermostated water bath $\left(20 \pm 1{ }^{\circ} \mathrm{C}\right)$. Small volumes of the solution of 1 were added to sonicated DNA solution placed in the viscometer. Mixing was effected by slowly bubbling dry nitrogen gas. Flow times were measured in triplicate to an accuracy of $\pm 0.01 \mathrm{~s}$ with an electronic stopwatch Casio Model HS-30W (Casio Computer Co. Ltd., Tokyo, Japan). Relative viscosities for DNA either in the presence or absence of $\mathbf{1}$ were calculated from the relation,

$$
\eta_{\text {sp }}^{\prime} / \eta_{\text {sp }}=\left\{\left(\mathrm{t}_{\text {complex }}-\mathrm{t}_{\mathrm{o}}\right) / \mathrm{t}_{\mathrm{o}}\right\} /\left\{\left(\mathrm{t}_{\text {control }}-\mathrm{t}_{\mathrm{o}}\right) / \mathrm{t}_{\mathrm{o}}\right\}
$$

where $\eta_{\mathrm{sp}}^{\prime}$ and $\eta_{\mathrm{sp}}$ are specific viscosities of the 1-DNA complex and the DNA, respectively; $t_{\text {complex }}, t_{\text {control }}$, and $t_{0}$ are the average flow times for the DNA-1 complex, free DNA and buffer, respectively.

\subsection{Circular dichroism spectroscopy}

The circular dichroism (CD) spectra were recorded on a JASCO J815 spectropolarimeter (Jasco International Co. Ltd, Hachioji, Japan) equipped with a Jasco temperature controller (model PFD 425L/15) interfaced with a HP PC at $20 \pm 0.5^{\circ} \mathrm{C}$ using instrument parameters reported previously. ${ }^{9}$

\subsection{Gel electrophoresis}

Cleavage of DNA by complex $\mathbf{1}$ was monitored by agarose gel electrophoresis technique. The DNA cleavage efficiency of complex was examined by determining their ability to convert supercoiled DNA (form I) to open circular (form II) and linear forms (form III). The cleavage experiments were carried out in the absence and presence of an activating agent. The complex 1 $(20 \mu \mathrm{M}, 40 \mu \mathrm{M}, 60 \mu \mathrm{M}, 80 \mu \mathrm{M}$ and $100 \mu \mathrm{M})$ was incubated with plasmid DNA in the absence and presence of hydrogen peroxide $(1 \mu \mathrm{M})$ overnight at $37^{\circ} \mathrm{C}$. One experiment was carried out incubating DNA with $20 \mu \mathrm{M}$ metal complex, $1 \mu \mathrm{M} \mathrm{H}_{2} \mathrm{O}_{2}$ and DMSO. A loading buffer containing $0.25 \%$ bromophenol blue, $40 \%$ (w/v) sucrose and $0.5 \mathrm{M}$ EDTA was added and the electrophoresis of the DNA cleavage products were performed on agarose gel containing ethidium bromide. The gels were run at $50 \mathrm{~V}$ for $2 \mathrm{~h}$ in Tris-boric acid-ethylenediamine tetra acetic acid (TBE) buffer at $\mathrm{pH}$ 7.4. The cleavage of DNA was monitored using $0.8 \%$ agarose gel electrophoresis containing $0.5 \mu \mathrm{g} / \mathrm{mL}$ ethidium bromide. The bands were viewed by placing the gel on UV illuminator and were photographed using gel documentation system.

\section{Results and discussion}

\subsection{Synthesis and formulation}

Ligand L was synthesized by 1:2 condensation of triethylenetetramine and 2-benzoylpyridine in dehydrated alcohol. 1 was prepared using reaction among Fe(III) salt and the ligand in methanol. The reduction of Fe(III) to $\mathrm{Fe}$ (II) was due to possibly by the oxidation of methanol which was used as solvent. ${ }^{10}$ The exact coordination sphere of $\mathbf{1}$ was determined by single-crystal $\mathrm{X}$-ray crystallography. In IR spectra, the well-resolved peaks at 1618 and $1592 \mathrm{~cm}^{-1}$ is due to $\mathrm{C}=\mathrm{N}$ stretch. ${ }^{11}$ 1 shows peaks at 1084 and $625 \mathrm{~cm}^{-1}$ due to symmetrical asymmetrical stretch of $\mathrm{ClO}_{4}^{-}$and weak bands in the range $2980-2900 \mathrm{~cm}^{-1}$ are due to the aliphatic $\mathrm{C}-\mathrm{H}$ stretching frequency. 


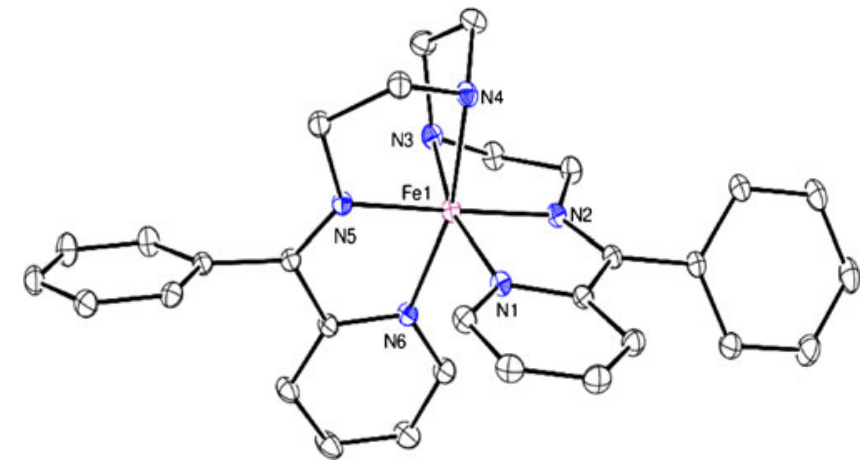

Figure 1. ORTEP of $\mathbf{1}$ with $30 \%$ ellipsoid probability.

\subsection{Description of crystal structure}

3.2a Structure of 1: Coordination geometry around iron(II) centre in 1 (figure 1) is best described as distorted octahedron with $\mathrm{FeN}_{6}$ chromophore. The bond angle and bond distance data are given in table 2 . Among the coordinating atoms N1, N6 are pyridine nitrogen atoms; $\mathrm{N} 2, \mathrm{~N} 5$ are imine and $\mathrm{N} 3, \mathrm{~N} 4$ are amine nitrogen atoms. Considering bond angle and bond distance data, it is assumed that N2 and N5 are at the axial position of the distorted octahedron and the rest N1, N3, N4, N6 are at the equatorial position. The Fe$\mathrm{N}$ bond distances range from 1.897(2) to 2.003(2) and the difference $\Delta$ between the longest and shortest bond amounts $0.106 \AA$.

\subsection{Studies on interaction of 1 with DNA and DNA cleavage}

3.3a UV/Vis spectroscopy: The DNA binding experiments were performed in Tris- $\mathrm{HCl}$ buffer $(50 \mathrm{mM}$ Tris$\mathrm{HCl}, \mathrm{pH}$ 8) using a tris base solution of the complex 1. The concentration of DNA was determined from the absorption intensity at $260 \mathrm{~nm}$ with an $\varepsilon$ value ${ }^{12}$ of

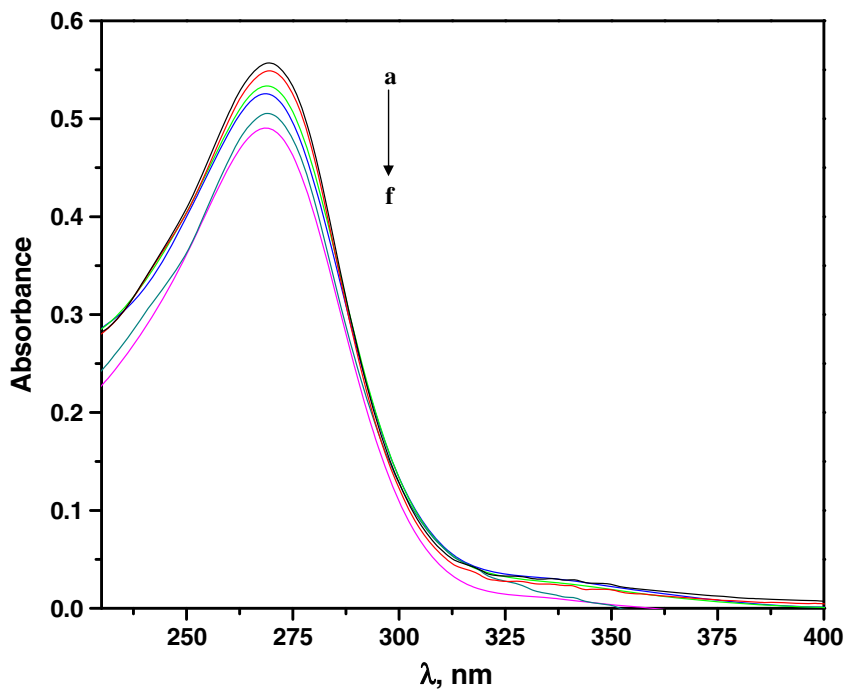

Figure 2. Electronic spectrum of the title complex through titration with DNA in Tris- $\mathrm{HCl}$ buffer; [Complex] $=1.02$ $\times 10^{-4} \mathrm{M}$; [DNA]: (a) 0.0 , (b) $2.0 \times 10^{-6}$, (c) $4.0 \times 10^{-6}$, (d) $6.0 \times 10^{-6}$, (e) $8.0 \times 10^{-6}$, (f) $1.0 \times 10^{-5} \mathrm{~mol} \mathrm{~L}^{-1}$. The increase of DNA concentration is indicated by an arrow.

$6600 \mathrm{M}^{-1} \mathrm{~cm}^{-1}$. Absorption titration experiments were made using different concentrations of DNA, while keeping the complex concentration constant. Due correction was made for the absorbance of the DNA itself. Samples were equilibrated before recording each spectrum. A broad spectrum in the range of $250-280 \mathrm{~nm}$ is shown in the UV-Vis spectrum of the complex (figure 2). After addition of DNA to the solution of $\mathrm{Fe}(\mathrm{III})$ complex in tris-buffer, it is clearly observed that the absorption peak at $270 \mathrm{~nm}$ undergoes a significant decrease in molecular absorption (hypochromic effect) with no detectable shift in the absorption wavelength. The gradual decrease in the absorption wavelength indicates some interaction of $\mathbf{1}$ with DNA double strand. The binding constant, $K_{\mathrm{b}}$ for the complex has

Table 2. Bond angle bond distance parameters for $\mathbf{1}$.

\begin{tabular}{lrlr}
\hline Bond distances & & & \\
$\mathrm{Fe}(1)-\mathrm{N}(1)$ & $1.959(2)$ & $\mathrm{Fe}(1)-\mathrm{N}(4)$ & $2.003(2)$ \\
$\mathrm{Fe}(1)-\mathrm{N}(2)$ & $1.897(2)$ & $\mathrm{Fe}(1)-\mathrm{N}(5)$ & $1.901(2)$ \\
$\mathrm{Fe}(1)-\mathrm{N}(3)$ & $1.999(2)$ & $\mathrm{Fe}(1)-\mathrm{N}(6)$ & $1.960(2)$ \\
Bond angles & & & \\
$\mathrm{N}(2)-\mathrm{Fe}(1)-\mathrm{N}(5)$ & $178.70(9)$ & $\mathrm{N}(1)-\mathrm{Fe}(1)-\mathrm{N}(3)$ & $165.00(9)$ \\
$\mathrm{N}(2)-\mathrm{Fe}(1)-\mathrm{N}(1)$ & $80.85(9)$ & $\mathrm{N}(6)-\mathrm{Fe}(1)-\mathrm{N}(3)$ & $91.99(9)$ \\
$\mathrm{N}(5)-\mathrm{Fe}(1)-\mathrm{N}(1)$ & $100.32(9)$ & $\mathrm{N}(2)-\mathrm{Fe}(1)-\mathrm{N}(4)$ & $94.52(9)$ \\
$\mathrm{N}(2)-\mathrm{Fe}(1)-\mathrm{N}(6)$ & $99.82(9)$ & $\mathrm{N}(5)-\mathrm{Fe}(1)-\mathrm{N}(4)$ & $84.89(9)$ \\
$\mathrm{N}(5)-\mathrm{Fe}(1)-\mathrm{N}(6)$ & $80.71(8)$ & $\mathrm{N}(1)-\mathrm{Fe}(1)-\mathrm{N}(4)$ & $92.35(9)$ \\
$\mathrm{N}(1)-\mathrm{Fe}(1)-\mathrm{N}(6)$ & $93.41(9)$ & $\mathrm{N}(6)-\mathrm{Fe}(1)-\mathrm{N}(4)$ & $165.23(9)$ \\
$\mathrm{N}(2)-\mathrm{Fe}(1)-\mathrm{N}(3)$ & $84.44(9)$ & $\mathrm{N}(3)-\mathrm{Fe}(1)-\mathrm{N}(4)$ & $85.85(9)$ \\
$\mathrm{N}(5)-\mathrm{Fe}(1)-\mathrm{N}(3)$ & $94.36(9)$ & & \\
\end{tabular}


been determined from the plot of $[\mathrm{DNA}] /\left(\varepsilon_{\mathrm{A}}-\varepsilon_{\mathrm{F}}\right)$ vs. $[\mathrm{DNA}]^{5}$ and found to be $3.5 \times 10^{3} \mathrm{M}^{-1}(\mathrm{R}=-0.9638$ for five points) (figure 3).

3.3b Fluorescence spectroscopy: The fluorescence spectral method using the standard intercalator ethidium bromide (EB) as a reference was used to determine the relative DNA binding properties of the complex to the DNA in tris-buffer $(5 \mathrm{mM}, \mathrm{pH} 8.0)$. Fluorescence intensities of EB in DNA were measured at different complex concentrations. The addition of the complex to the DNA pretreated with EB causes an appreciable reduction in the fluorescence intensity (figure 4) indicating that $\mathbf{1}$ competes with EB to bind with DNA. The reduction of the emission intensity gives a measure of the DNA binding propensity of the complex and stacking interaction (intercalation) between adjacent DNA base pairs. ${ }^{13}$ The relative binding tendency of the complex with the DNA was determined from the comparison of the slope of the lines in the fluorescence intensity versus complex concentration plot.

The quenching of EB bound to DNA by the title complex is in agreement with the linear Stern-Volmer equation:

$$
\mathrm{I}_{0} / \mathrm{I}=1+K_{\mathrm{sv}}[\text { complex }],
$$

where $\mathrm{I}_{0}$ and I represent the fluorescence intensities in the absence and presence of quencher, respectively. $K_{\mathrm{sv}}$ is the linear Stern-Volmer quenching constant and [complex], the concentration of the quencher. From the

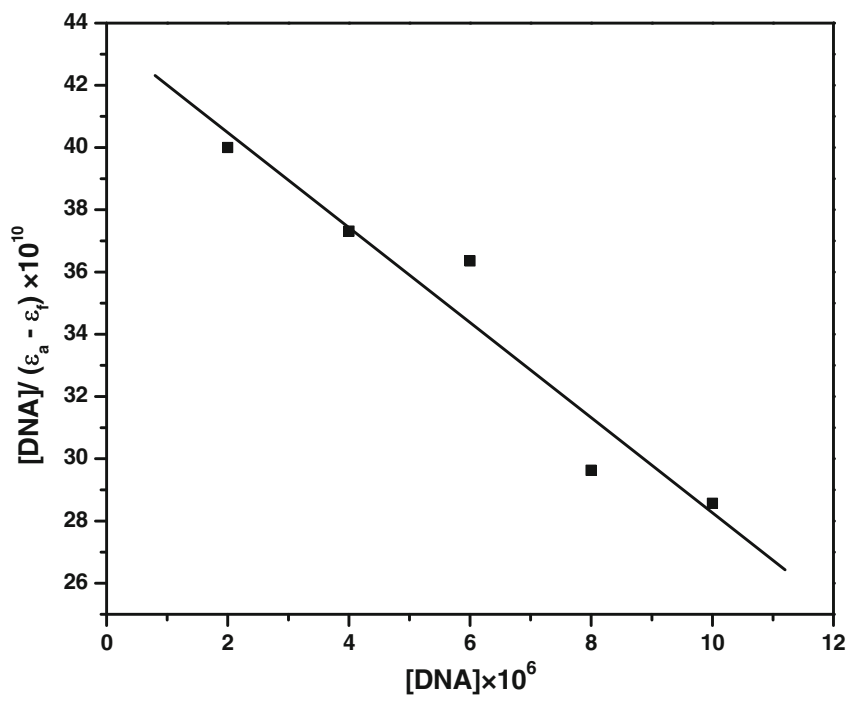

Figure 3. Plot of [DNA] $/\left(\varepsilon_{A}-\varepsilon_{F}\right)$ vs. [DNA] for the titration of DNA with 1 in Tris- $\mathrm{HCl}$ buffer, binding constant $K_{\mathrm{b}}=3.5 \times 10^{3} \mathrm{M}^{-1}(\mathrm{R}=-0.9638$ for five points $)$.

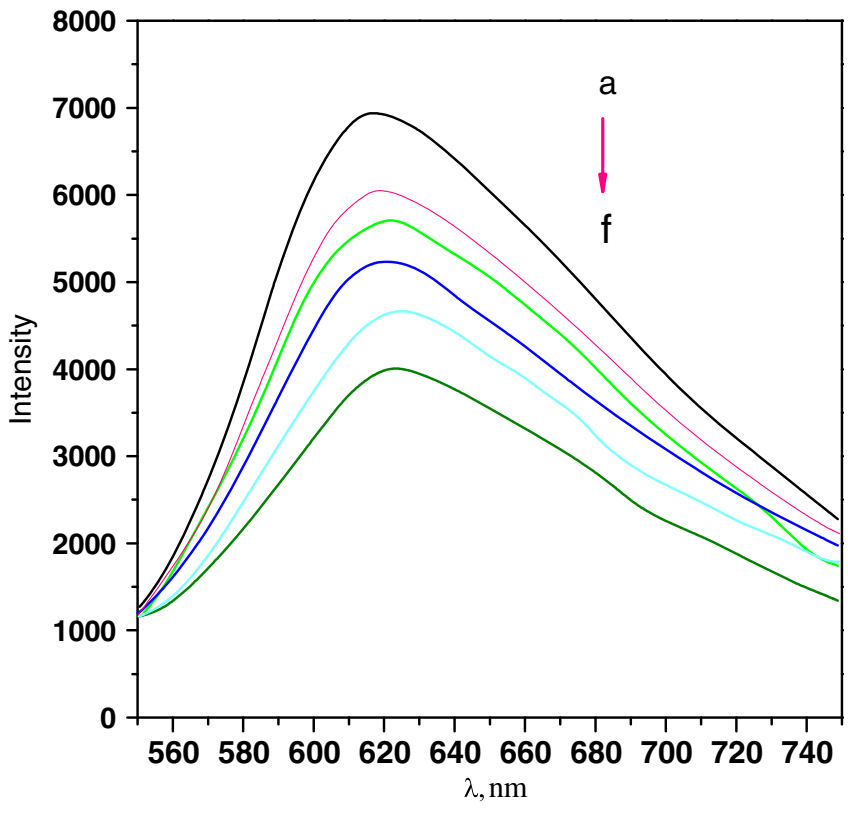

Figure 4. Fluorescence spectra of the DNA-EB system in Tris- $\mathrm{HCl}$ buffer based on the titration of $1 . \mathrm{k}_{\mathrm{ex}}=522 \mathrm{~nm}$; The arrow indicates the increase of the complex concentration.

slope of the regression line in the derived plot of $\mathrm{I}_{0} / \mathrm{I}$ versus [complex] (figure 5), the $K_{\mathrm{sv}}$ value for the complex was found to be $2.73 \times 10^{4} ;(\mathrm{R}=0.9917$ for five points $)$ indicating a strong affinity of the complex to DNA.

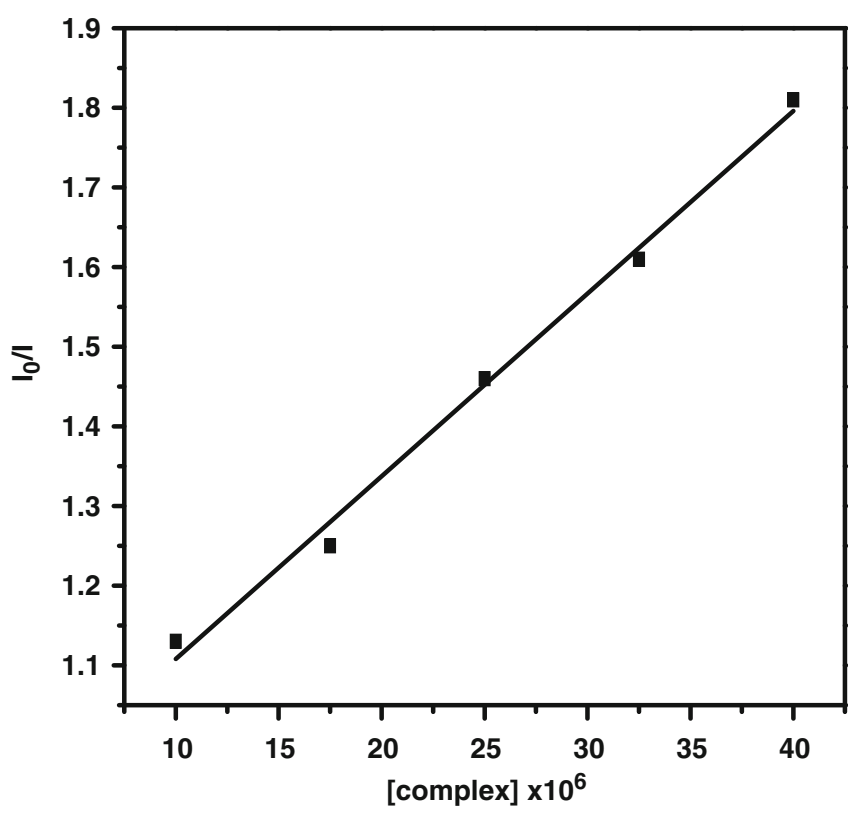

Figure 5. Plot of $\mathrm{I}_{0} / \mathrm{I}$ vs. [complex] for the titration of DNA-EB system with $\mathbf{1}$ using spectrofluorimeter; linear Stern-Volmer quenching constant $\left(K_{\mathrm{sv}}\right)_{1}=2.73 \times 10^{4} \mathrm{M}^{-1}$; ( $\mathrm{R}=0.9917$ for five points). 
3.3c Thermal melting studies: The binding was further tested from optical thermal melting studies. ${ }^{14}$ Double stranded DNA under the conditions of the experiment had a melting temperature $\left(T_{m}\right)$ of $78^{\circ} \mathrm{C}$ (figure 6). The melting temperature of the native DNA enhanced in the presence of the complex and at saturation $\Delta T_{m}$ value of $3^{\circ} \mathrm{C}$ was observed when the $\mathrm{D} / \mathrm{P}$ (DNA/1) ratio is 0.8 . The $\Delta T_{m}$ value is $6.5^{\circ} \mathrm{C}$ when the $\mathrm{D} / \mathrm{P}$ ratio is 2.0. Such high stabilization of the DNA helix is essentially due to the strong binding of $\mathbf{1}$ either in the grooves or by intercalation or by both modes.

3.3d Hydrodynamic studies: To further probe and distinguish between a groove binding, intercalative or partial intercalative and groove binding modes, viscosity of the DNA solution was measured in the presence of increasing concentrations of $\mathbf{1}$ and the change in relative viscosities with varying inputs of $\mathbf{1}$ were estimated. ${ }^{15}$ Hydrodynamic method provides unequivocal evidence for the mode of binding. ${ }^{16,17}$ An intercalative ligand ethidium bromide is known to increase the basepair separation with an increase in the relative viscosity of the DNA. In contrast, groove or surface binding cause a decrease in the effective length of DNA leading to a minor decrease in the relative viscosity of the DNA solution. ${ }^{18}$ The relative specific viscosity of the DNA-1 complex increased steadily as the D/P (complex/DNA molar ratio) increased and ultimately attained saturation at $\mathrm{D} / \mathrm{P} \geq 1.0$ (figure 7). A control experiment was also performed with the classical intercalator EB. A comparative study was performed with the classical intercala-

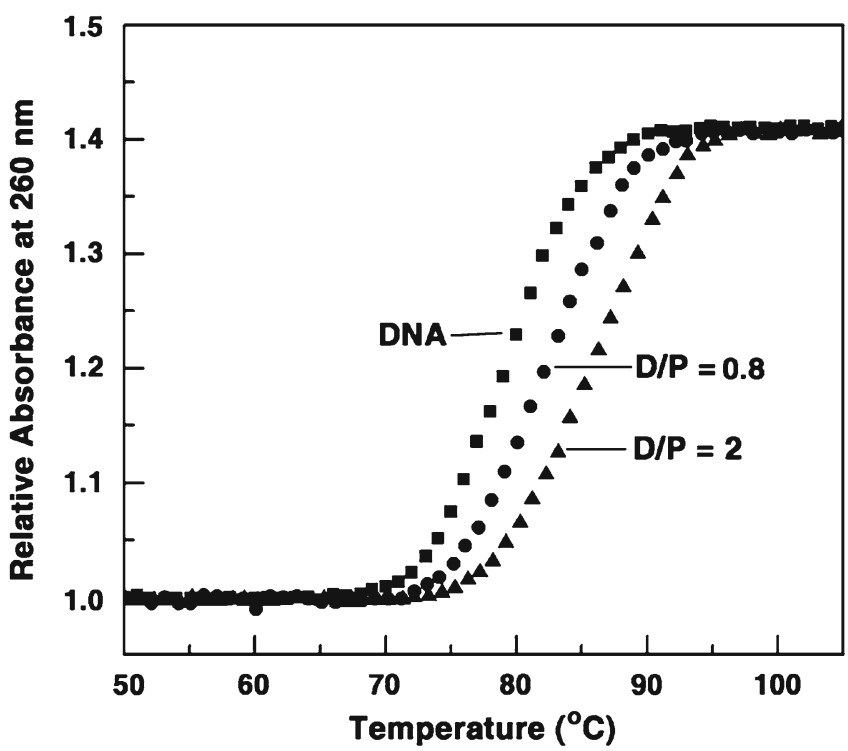

Figure 6. Thermal melting profile (relative absorbance change at $260 \mathrm{~nm}$ versus temperature $)$ of DNA $(20 \mu \mathrm{M})$ and its complex with $1(\mathrm{D} / \mathrm{P}=0.8$ and $\mathrm{D} / \mathrm{P}=2.0)$.

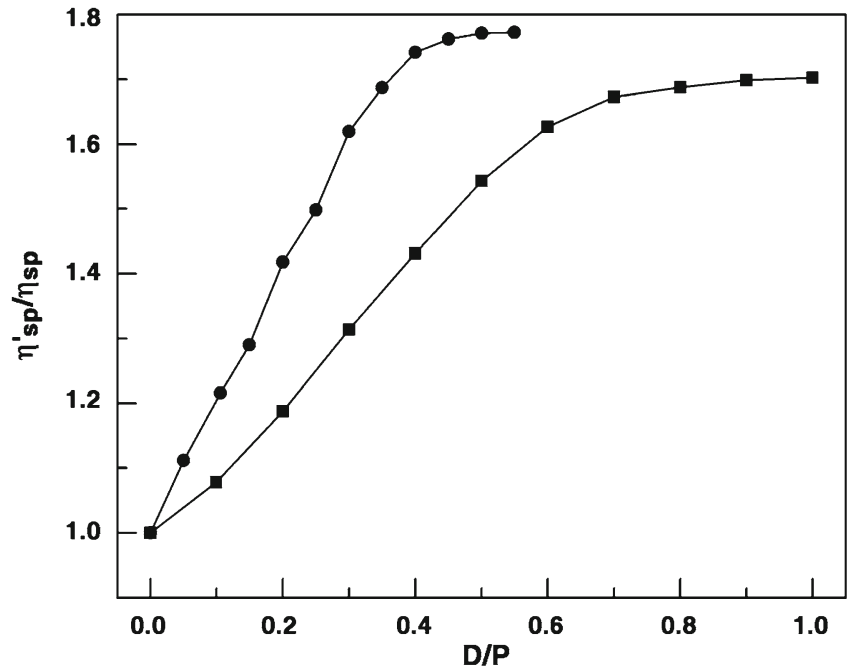

Figure 7. Plot of $\eta_{\mathrm{sp}}^{\prime} / \eta_{\mathrm{sp}}$ versus $\mathrm{D} / \mathrm{P} \quad[\mathrm{DNA} / \mathrm{EtBr} \quad(\bullet)$, DNA/Fe-complex (ם)].

tor EB. The results favour a intercalative binding mode of the iron complex into the double helical organization of the DNA.

3.3e Circular dichroism studies: The circular dichroism (CD) spectra of the DNA duplex displayed a canonical B-form conformation characterized by a positive band in the $275 \mathrm{~nm}$ and a negative band around $248 \mathrm{~nm}$. These bands are caused due to the stacking interactions between the base pairs and the helical structure of the duplex that provide asymmetric

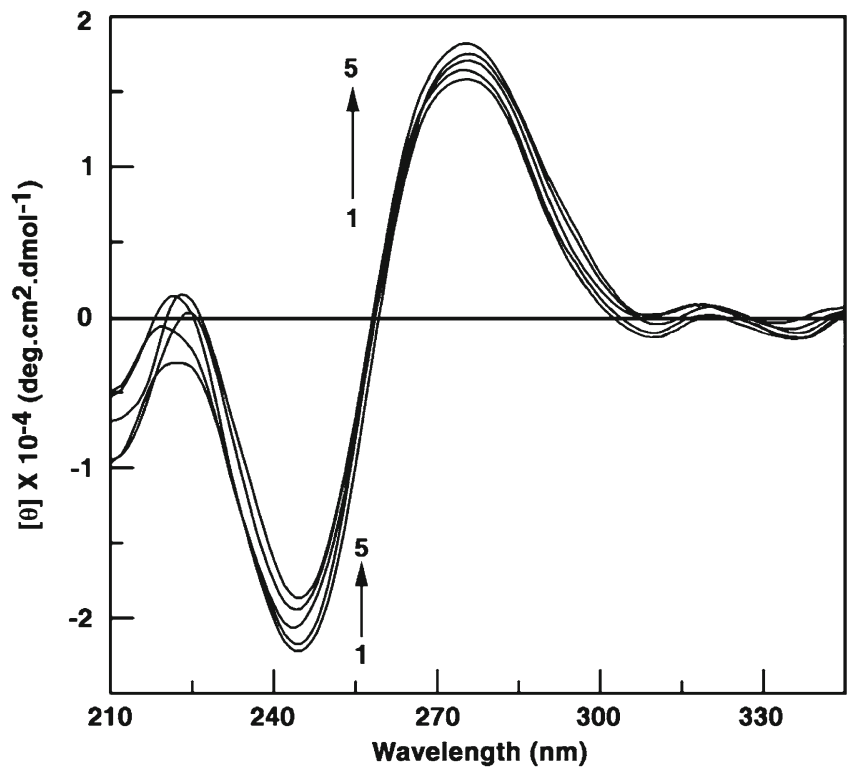

Figure 8. Representative $\mathrm{CD}$ spectra resulting interaction of Fe-complex with DNA at $\mathrm{pH} 7.2$ in Tris- $\mathrm{HCl}$ buffer (50 mM): curves $1-5$ denote DNA $(30 \mu \mathrm{M})$ treated with 0,18 , 36,48 and $60 \mu \mathrm{M}$ of Fe-complex. 


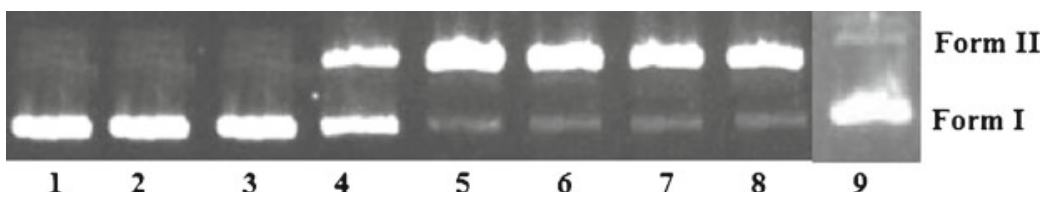

Figure 9. Concentration dependant cleavage of SC pUC 18 DNA upon addition of 1 in the presence of $\mathrm{H}_{2} \mathrm{O}_{2}$. DNA (400 ng) was incubated with the complex of various concentrations for $12 \mathrm{~h}$ in Tris buffer ( $\mathrm{pH}$ 7.2) Lane 1, DNA control; lane 2, DNA + complex; lane 3 , DNA + peroxide $(1 \mu \mathrm{M})$ alone; lane 4, DNA + complex $(20 \mu \mathrm{M})+\mathrm{H}_{2} \mathrm{O}_{2}(1 \mu \mathrm{M})$; lane 5, DNA + complex $(40 \mu \mathrm{M})+\mathrm{H}_{2} \mathrm{O}_{2}(1 \mu \mathrm{M})$; lane 6 , DNA + complex $(60 \mu \mathrm{M})+$ $\mathrm{H}_{2} \mathrm{O}_{2}(1 \mu \mathrm{M})$; lane 7 , DNA + complex $(80 \mu \mathrm{M})+\mathrm{H}_{2} \mathrm{O}_{2}(1 \mu \mathrm{M})$; lane 8, DNA + complex $(100 \mu \mathrm{M})+\mathrm{H}_{2} \mathrm{O}_{2}(1 \mu \mathrm{M})$; lane 9 , DNA + complex $(20 \mu \mathrm{M})+\mathrm{H}_{2} \mathrm{O}_{2}(1 \mu \mathrm{M})+$ DMSO.

environment for the bases. To record the iron complex induced changes in the DNA conformation, the CD spectra in the $220-400 \mathrm{~nm}$ regions were recorded (figure 8) in the presence of increasing concentration of 1. The intensity of the long wavelength positive band decreased in ellipticity as the interaction progressed with a slight red shift in the wavelength maximum. Moderate changes were also observed in the negative CD band at $248 \mathrm{~nm}$ that decreased in ellipticity. The intrinsic CD contribution of the ligand has been subtracted in each case.

3.3f Gel electrophoresis: The Fe(II) complex 1 when incubated with plasmid DNA did not bring about any DNA cleavage as can be seen from the figure 9 (lane 2). In the presence of external additive, viz. hydrogen peroxide, the complex brought about DNA cleavage in a concentration dependent manner (lanes 38). Results show that Fe(II) complex brought about oxidative cleavage of DNA. With increasing concentra-

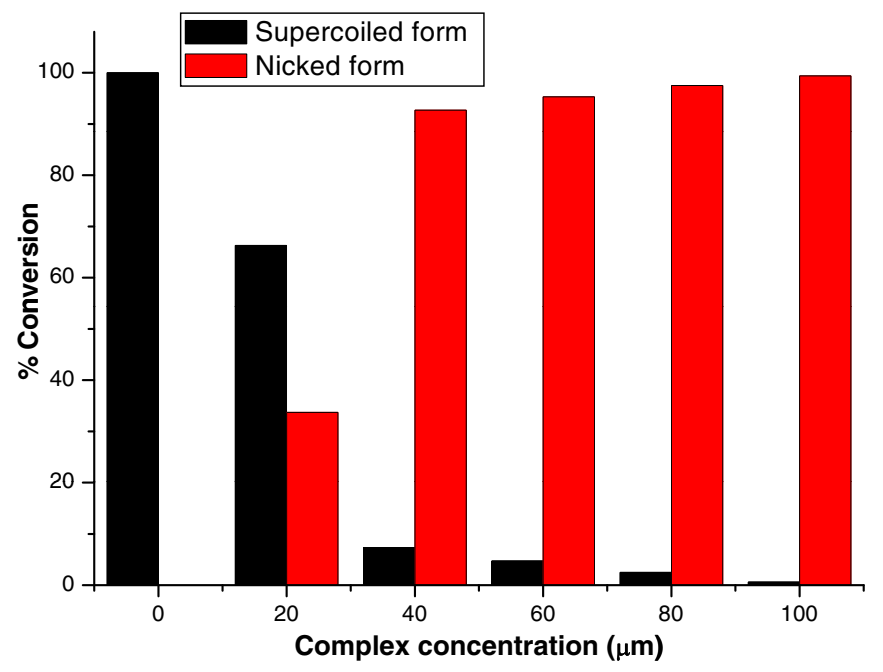

Figure 10. Percentage of conversion of DNA from super coiled to nicked form with increasing complex concentration. tion of the complex $(20 \mu \mathrm{M}, 40 \mu \mathrm{M}, 60 \mu \mathrm{M}, 80 \mu \mathrm{M}$ and $100 \mu \mathrm{M}$ ) supercoiling form of DNA (form I) was converted to nicked circular form (form II). At the initial concentration of $20 \mu \mathrm{M}$ of complex complete conversion of supercoiled form to nicked form was not observed (lane 4). However, at higher concentration of the metal complex complete conversion of supercoiled form of DNA to the open circular form was observed. The last lane represents the inhibition of supercoiled to nicked form of DNA incubated with complex in the presence of DMSO. This confirms that hydroxyl radical is the reactive oxygen species involved in the oxidative cleavage of DNA. With the increase in complex concentration (keeping the concentration of the hydrogen peroxide constant) the percentage of conversion of supercoiled DNA to its nicked form is found to be increased (figure 10). In the presence of $100 \mu \mathrm{M}$ complex concentration cent percent conversion of the DNA from its supercoiled to nicked form is effected (figure 10) here.

\section{Conclusions}

In the present investigation, we have reported the synthesis, single crystal X-ray structural characterization of an iron(II) complex (1) with a neutral Schiff base ligand L. Similar type of complexes with other metal ions were reported ${ }^{19}$ by our group in recent time. Here, interaction of 1 with DNA has been studied. The binding constant for the complex is found to be $3.5 \times 10^{3} \mathrm{M}^{-1}$ ( $\mathrm{R}=-0.9638$ for five points). The linear Stern-Volmer quenching constant was determined as $2.73 \times 10^{4} \mathrm{M}^{-1}$ ( $\mathrm{R}=0.9917$ for five points). The complex 1 enhanced the thermal stabilization of native DNA by $6^{\circ} \mathrm{C}$ clearly suggesting strong stabilization effects. Viscosity measurements provided evidence for intercalation of $\mathbf{1}$ into the DNA double helix. Conformational changes of DNA within the B-form induced by $\mathbf{1}$ further testified 
for the interaction of the complex with double stranded DNA. Overall, studies indicate an intercalative binding mode of 1 with the DNA. 1 also induces concentration dependent oxidative cleavage of the supercoiled DNA. In comparison to some other reported complexes, ${ }^{1 b, 19 a}$ the oxidizing agent required in DNA cleavage activity in our case is much less. Using this small concentration $(1 \mu \mathrm{M})$ of oxidizing agent $100 \%$ conversion of DNA from its supercoiled to nicked form is possible.

\section{Supplementary data}

CCDC 897145 contains the supplementary crystallographic data for $\mathbf{1}$. These data can be obtained free of charge via http://www.ccdc.cam.ac.uk/conts/retrieving. $\mathrm{html}$, or from the Cambridge Crystallographic Data Centre, 12 Union Road, Cambridge CB2 1EZ, UK; fax: (+44) 1223-336-033; Email: deposit@ccdc.cam.ac.uk.

\section{Acknowledgements}

Financial support by the Department of Science and Technology (DST), New Delhi, India (F. No. SR/FT/CS83/2010 dt. 11-02-2011) is gratefully acknowledged by RG. MM and SH are thankful to the University of Burdwan and Council for Scientific and Industrial Research (CSIR), New Delhi, India, respectively for Junior Research Fellowships.

\section{References}

1. (a) Keene F R, Smith J A and Collins J G 2009 Coord. Chem. Rev. 253 2021; (b) Dhara K, Ratha J, Manassero M, Wang X-Y, Gao S and Banerjee P 2007 J. Inorg. Biochem. 101 95; (c) Uma V, Castineiras A and Nair B U 2007 Polyhedron 26 3008-3016; (d) Kumar P, Garai S, Santra M K, Mondal B and Manna D 2012 Dalton Trans. 417573

2. Basu U, Khan I, Hussain A, Kondaiah P and Chakravarty A R 2012 Angew. Chem. Int. Ed. 51 2658; (b) Basu U, Khan I, Koley D, Saha S, Kondaiah P and Chakravarty A R 2012 J. Inorg. Biochem. 116 77; (c) Vijayalakhmi R, Kanthimathi M, Parthasarathi R and Nair B U 2006 Bioorg. Med. Chem. 143300
3. (a) Anbu S and Kandaswamy M 2011 Polyhedron 30 123; (b) Roy S, Patra A K, Dhar S and Chakravarty A R 2008 Inorg. Chem. 47 5625; (c) Wang Q X, Jiao K, Sun W, Jian F F and Hu X 2006 Eur. J. Inorg. Chem. 1838

4. (a) Liu C, Wang M, Zhang T and Sun H 2004 Coord. Chem. Rev. 248 147; (b) Trawick B N, Daniher A T and Bashkin J K 1998 Chem. Rev. 98939

5. Pal A, Biswas B, Mondal S K, Lin C-H and Ghosh R 2012 Polyhedron 31671

6. Chowdhury H, Ghosh R, Rahaman S H and Ghosh B K 2007 Polyhedron 265023

7. Bruker 2007 SMART, SAINT and SADABS (Madison, Wisconsin, USA: Bruker AXS Inc.)

8. Sheldrick G M 1999 SHELXL-97 (Göttingen, Germany: University of Göttingen)

9. Bhadra K, Maiti M and Suresh Kumar G 2007 Biochim. Biophys. Acta 17701071

10. Biswas B, Hunaiti A A, Räisänen M T, Ansalone S, Leskelä M, Repo T, Chen Y -T, Tsai H -L, Naik A D, Railliet A P, Garcia Y, Ghosh R and Kole N 2012 Eur. J. Inorg. Chem. 4479

11. (a) Nakamoto K 2009 Infrared and Raman spectra of inorganic and coordination compounds, part B: Applications in coordination, organometallic and bioinorganic chemistry, New York, Sixth Ed (New Jersey: John Wiley \& Sons Inc)

12. Reichmann M E, Rice S A, Thomas C A and Doty P 1954 J. Am. Chem. Soc. 763047

13. Lepecq J B and Paoletti C 1967 J. Mol. Biol. 2787

14. Hossain M and Suresh Kumar G 2009 Mol. Bio. Syst. 5 1311

15. Sinha R, Islam M M, Bhadra K, Suresh Kumar G, Banerjee A and Maiti M 2006 Bioorg. Med. Chem. 14 800

16. Satyanarayana S, Dabrowiak J C and Chaires J B 1993 Biochemistry 322573

17. (a) Sasmal P K, Patra A K, Nethaji M and Chakravarty A R 2007 Inorg. Chem. 46 11112; (b) Mahadevan S and Palaniandavar M 1998 Inorg. Chem. 37 693; (c) Yang X-B, Huang Y, Zhang J-S, Yuan S-K and Zeng R-Q 2010 Inorg. Chem. Commun. 131421

18. (a) Kapicak L and Gabbay E J 1975 J. Am. Chem. Soc. 97 403; (b) Pellegrini P P and Aldrich-Wright J R 2003 Dalton Trans. 176; (c) Roy M, Santhanagopal R and Chakravarty A R 2009 Dalton Trans. 1024

19. (a) Biswas B, Raghavaiah P, Aliaga-Alcalde N, Chen J -D and Ghosh R 2010 Polyhedron 29 2716; (b) Biswas B, Pal A, Krishna G R, Reddy C M, Tuna F and Ghosh R 2011 Polyhedron 302032 